\title{
The Influence of Storytelling Method on Language Development
}

\author{
Novita Widiyaningrum, Siti Masitoh, Rachma Hasibuan. \\ Universitas Negeri Surabaya \\ Surabaya Indonesia \\ novitawidiyaningrum@gmail.com
}

\begin{abstract}
This study aimed to analyze the influence of storytelling through picture card on expressive language development of children aged 5 to 6 years. This study used a quantitative approach method. The independent variable was the storytelling method through picture card while the dependent variable is the expressive language development. The sample was group B students of some kindergartens. Data were collected using observation and analyzed using one-way ANOVA. The results showed that storytelling method through image card influenced children's expressive language in East Java. It is suggested that early childhood teachers can utilize visualization media that can attract students' attention using storytelling through picture card which is interesting, funny and can make children laugh.
\end{abstract}

Keywords-storytelling method; picture card; expressive language

\section{INTRODUCTION}

Early childhood education concerns on whole effort and action like taking care, nurturing, and educating children by creating an environment where children can explore their learning experiences.

The problem faced by group B children of kindergarten in sub-district of Sidoarjo is linguistic aspects such as the ability to listen and speak that are still low. This may be caused by some internal factors such as children are ashamed to express opinions such as repeating the story that has been played, children get bored easily that makes them difficult to concentrate, children are drilled to read, write and count to prepare them for the next level of education. Another factor is an external factor, such as the teachers use the monotonous learning method and are low in mastering the class well, teachers are more likely to use children's worksheets to learn to write and count in the preparation of children to the next level, learning media presented in the learning process is less varied. The result of those problems could be seen when teachers asked children and they were ashamed and unable to answer and express ideas because of limited vocabulary. Thus, these problems made children have a low ability of mastery aspects of the language especially listening and speaking.

Early childhood intelligence is an ability to express ideas about themselves and to understand others and to learn new vocabulary or other languages [1]. [2] states that listening and listening is a process of learning to speak naturally and through the process, children learn to speak.

Storytelling is a way used by teachers in learning based on the basic purpose of language skills of children. The writer chose storytelling method to stimulate aspects of language development in terms of listening and speaking of group B children in Kindergartens because learning method can develop the imagination, creativity, and thinking the power of children language development, especially the ability to speak children [3].

Referring to the background, the writer conducted research entitled "The Influence of Storytelling Method on Language Development". Therefore, this study aimed to analyze the influence of the telling method on expressive language development of children aged 5-6 years. The regulation of ministry of national education No. 58 the year 2009 states that the level of achievement describes the growth and development that is expected to be achieved by children in a certain age.

[1] suggests that language is central to society. Language forms the basis of perception, communication, and daily interaction. Language is a symbol system that categorizes, organizes, and clarifies the thoughts of each individual [1]. Speaking is included in expressive language skills. [1] states the ability to speak is an expression in the form of words. Some are receptive (understandable and acceptable) or expressive.

The capability to express an expressive language of children aged 3-5 years old includes in combinatory development where they have been able to speak in structured grammar understood by others and can respond to both positive and negative positives of conversation opponent [4]. Thus, it is inferred that development of the expressive language is the ability to use all language skills to express and interpret language that consists of pronunciation, the grammar (the forms and the structure of the sentences), and the brothers [5].

\section{METHOD}

This is an experimental study. There are two variables; the independent variable and dependent variable. Free variable in this research is a storytelling method through picture card (X) 
and the dependent variable is the development of expressive language $(\mathrm{Y})$.

The storytelling method can be an activity to listen to oral speech that tells an event that can be listened and felt directly, not only through listening but also vision where the teacher presents the story through the picture card.

The activities continue some of the stories that have been played by the teacher and able to answer characters in the story.

The populations in this study were Kindergarten children in sub-district of Sidoarjo, Sidoarjo district. The sample was 22 group B students. The sample was selected using random sampling.

The data were collected using observation before and after the storytelling through picture card. Data collection on research variables is data of children's activities through observation during storytelling. The observation sheet for children's activity is the instrument used in this study. Observation is done by looking at the children's activities in telling a story through picture card.

The quantitative data were collected in this study then analyzed using statistical formulas using computer services (SPSS). Activities in data analysis consists of grouping or tabulating data based on variables of all respondents, presenting data of each variable studied, perform calculations to answer the formulation of the problem, and perform calculations to test the hypothesis that has been proposed.

Data obtained were analyzed using one-way ANOVA used to test between 3 or more groups of interval-scale data or ratios derived from 1 independent variable. The purpose of this design is to study the influence of free and simultaneous variables from two or more independent variables on the final result. The variables in this study consist of two dependent variables and one independent variable (Winarsunu, 2012: 12). One-way ANOVA is used to see the effect of variable $\mathrm{X}$ on variable $\mathrm{Y}$.

Descriptive analysis is used to describe group B children's expressive language development in Sidoarjo sub-district Sidoarjo consisting of 3 children in the control group and 13 children in the experimental group. It can be seen that score of group interval was 0.75 so that it can be categorized such criteria as follows The result of expressive language development variables through picture card in group B of Kindergartens in the sub-district of Sidoarjo in Sidoarjo District are as follows: shows that the average score of the experimental group in post-test is 3.7692 (categorized as capable without teacher's assistance) better than control group of 3.1111 (categorized as capable with teacher's assistance).

\section{RESULTS AND DISCUSSION}

\section{Test of ANOVA}

The significant level is greater than 0.05 . this test is aimed to know whether there is or not deviations on the variables in the model. here are following requirement test as follows: This test used samples Kolmogorov-Smirnov, where the result of variables in this study. shows that the score of asymp.sig (2 tailed) for the language development variables in pretest and posttest is 0.593 and $0.141 \geq 0.05$, meaning that data are normally distributed. The homogeneity can be done by using Levene's, based on significance level score of Levene F observed. The results of the homogeneity can be seen in Table 7 below:

The ANOVA data analysis is done after analyzing requirements analysis, which aims to test the hypothesis that is "there is the influence of storytelling method through picture card on expressive language development of group $b$ children aged 5-6 years in kindergarten in the sub-district of sidoarjo, sidoarjo district ". Here is the result of statistical analysis by using ANOVA Test with SPSS 20:

TABLE 8. ANOVA SCORE

ANOV A

Perkembangan Bahasa Ekspresif (Post Test)

\begin{tabular}{|l|r|r|r|r|r|}
\hline & Serkembangan of & df & Mean Square & F & Sig. \\
\hline Between Groups & 2.303 & 1 & 2.303 & 8.087 & .010 \\
Within Groups & 5.697 & 20 & .285 & & \\
Total & 8.000 & 21 & & & \\
\hline
\end{tabular}

ANOVA test shows that $\mathrm{F}$ observed of significance level is $0.010<0.05$, meaning that there is the different development of expressive language between the control group and experimental group. it can be said that image storytelling method through picture card influences group b children's expressive language development in sub-district of Sidoarjo, the district of Sidoarjo. thus, the hypothesis is accepted.

The results of the study showed that storytelling through picture card influences expressive language development of group B children of Kindergarten in sub-district of Sidoarjo, district of Sidoarjo. The average score of children's expressive language development in the experimental group in post-test is 3.7692 (categorized as capable without teacher's assistance) better than a control group of 3.1111 (categorized as capable with teacher's assistance).

The results are in line with Hurlock (in Madyawati, 2016: 90) states that children's speaking skills should be supported by the vocabulary that is appropriate to the children's level of language development. Learning to speak at an early age can be used as a means of socialization like making friends and training their independence. This result of the study is also supported by Muliadi (2007: 66) who suggests that early childhood teachers can develop storytelling activities for children so that they can have good speaking skill because children learn to speak in a pleasant style and add to his vocabulary and language when telling the story.

\section{CONCLUSION}

It can be concluded that there is a significant influence of storytelling method through picture card on expressive language development of group $b$ children in Kindergarten the sub-district of Sidoarjo, Sidoarjo district. It can be seen from significant differences in expressive language development of experimental groups with the storytelling method through 
picture media which has a better score than the control group with the conventional method.

It is suggested that early childhood teachers can utilize visualization media that can attract students' attention using storytelling through picture card which is interesting, funny and can make children laugh. If the teacher uses an interesting picture card, it can play an important role as means of communication.

\section{REFERENCES}

[1] Kontos S, Wilcox-Herzog A. Influences on children's competence in early childhood classrooms. Early Childhood Research Quarterly. 1997 Jan 1;12(3):247-62.

[2] Murphy JM. Oral communication in TESOL: Integrating speaking, listening, and pronunciation. Tesol Quarterly. 1991 Mar;25(1):51-75.

[3] Musfiroh T. Memilih, menyusun, dan menyajikan cerita untuk anak usia dini. Yogyakarta: Tiara Wacana. 2008.

[4] Newkirk T, McClure P. Telling stories. Language development: A reader for teachers. 1996:1327138.

[5] Altmann G, Shillcock R. Cognitive models of speech processing: The second Sperlonga meeting. Psychology Press; 2013 May 24.

[6] Trousdale AM. Interactive storytelling: Scaffolding children's early narratives. Language Arts. 1990 Feb 1;67(2):164-73.

[7] Patterson K, Wright AE. The speech, language or hearing-impaired child: At-risk academically. Childhood Education. 1990 Dec 1;67(2):917.

[8] Leonard LB, Schwartz RG, Chapman K, Rowan LE, Prelock PA, Terrell B, Weiss AL, Messick C. Early lexical acquisition in children with specific language

[9] Cooper PM. Literacy learning and pedagogical purpose in Vivian Paley's 'storytelling curriculum'. Journal of Early Childhood Literacy. 2005 Dec;5(3):229-51. impairment. Journal of Speech, Language, and Hearing Research. 1982 Dec 1;25(4):554-64.

[10] Kuhl PK. Early language acquisition: cracking the speech code. Nature reviews neuroscience. 2004 Nov;5(11):831. 
